\title{
The Anatomical Distribution of Murine Toxin in Spheroplasts of Pasteurella pestis
}

\author{
By T. C. MONTIE and S. J. AJL \\ Research Laboratories, Department of Biochemistry, Albert Einstein Medical Center, \\ Philadelphia, Pennsylvania, U.S.A.
}

(Received 8 July 1963)

\begin{abstract}
SUMMARY
In order to study the distribution of the murine toxin in Pasteurellapestis, whole organisms were converted to spheroplasts by treatment with penicillin or glycine in a sucrose medium. The spheroplasts were broken by osmotic lysis and homogenization. After centrifugation and washing, the membrane residues contained about $10 \%$ of the total activity of the spheroplast; the remainder of the toxic activity resided within the cytoplasm. Ribosomes were of low toxic activity. Magnesium ions selectively inhibited the destruction of these membranes by sonic oscillation; their treatment with trypsin resulted in the release of large amounts of non-toxic protein and peptides. Varying the temperature during spheroplast formation altered both the distribution of toxin between the anatomical components as well as the amount of toxin synthesized. Preliminary tests indicated that toxin obtained from the membrane and that found within the cytoplasm were identical.
\end{abstract}

\section{INTRODUCTION}

Ajl, Reedal, Durrum \& Warren (1955) isolated, purified and described the murine toxin of Pasteurella pestis as a non-conjugated protein of about 74,000 molecular weight. It has been observed by a number of workers that this toxin is intracellular and that it can be released following lysis or autolysis of the organisms (Englesberg \& Levy, 1954; Goodner, Pannel, Bartell \& Rothstein, 1955; Warren, Walz, Reedal \& Ajl, 1955). Cocking, Keppie, Witt \& Smith (1960) submitted Pasteurella pestis grown in vivo to sonic oscillation. They found that toxicity for mice resided predominantly in the resulting extract while a small amount of toxic activity remained in the residue. We have observed the bulk of the toxin to be present in the extracts as well as some in the cell wall from sonically treated organisms grown in vitro (unpublished data). The present report presents a somewhat different approach to the problem of toxin localization within the organisms. The possibility that certain breaking procedures might lead to erroneous conclusions about toxin distribution in growing organisms prompted our use of spheroplasts, in lieu of parent organisms, in order to eliminate this possibility as well as to demonstrate whether or not toxin resided within the cell membrane, cytoplasm or ribosomes. The results described here represent an attempt to further elucidate the anatomical site of toxin biosynthesis within the bacterial cell. In these investigations we have assumed a spheroplast to be devoid of the characteristic rigid bacterial cell wall of the parent organism from which it was derived. 


\section{METHODS}

Culture of cells and production of spheroplasts. Organisms of Pasteurella pestis strain 'Tjiwidej' used in these studies were obtained from a modified defined medium of Englesberg (1952) and Englesberg \& Levy (1954) in which casein hydrolysate was replaced by sodium thiosulphate $(500 \mathrm{mg} . / \mathrm{l}$.) and five L-amino acids : phenylalanine (1.0 $\mathrm{mm})$, methionine $(0.5 \mathrm{~mm})$, isoleucine $(1.0 \mathrm{~mm})$, threonine $(1.0 \mathrm{~mm})$ and valine $(1.0 \mathrm{~mm})$. Vitamins were added in the following amounts ( $\mu \mathrm{g} . / \mathrm{l}$.$) : thiamine hydrochloride (200), biotin (10), pyridoxine hydrochloride (100),$ folic acid (100), and cobalamin (50) containing $3000 \mu \mathrm{g} . / \mathrm{g}$. vitamin B-12. The amino acids and vitamins, sterilized by filtration, and glucose $(0 \cdot 2 \%, \mathrm{w} / \mathrm{v})$ solution, separately sterilized by heat were added to the autoclaved salt solution.

Organisms were stored on agar slopes composed of the defined medium containing $\mathbf{1 \cdot 6} \%$ agar. Transfers were made from slopes to liquid media and the suspension incubated at $26^{\circ}$ for $24 \mathrm{hr}$. The resulting suspension, stored at $7^{\circ}$, was used for daily inoculations. An inoculum (1.5 ml.) was transferred to $150 \mathrm{ml}$. of medium to produce actively growing cultures after incubation at $26^{\circ}$ for $16-19 \mathrm{hr}$ on a rotary shaker. The organisms were centrifuged down, washed in $0.054 \mathrm{M}$ potassium phosphate buffer ( $\mathrm{pH} 7 \cdot 0$ ), and standardized by resuspending in defined medium to a Klett reading of 25 with a no. 42 filter $(400-465 \mathrm{~m} \mu)$; this corresponded to a concentration of $40 \mu \mathrm{g}$. Lowry protein $/ \mathrm{ml}$. Sucrose to $10 \%(\mathrm{w} / \mathrm{v})$ and penicillin G (Parke, Davis and Co.), 200 units/ml., were then added. In certain experiments, glycine $(1 \%, \mathrm{w} / \mathrm{v})$ replaced the penicillin. When glycine was used, a concentration of organisms giving a Klett reading of $100(160 \mu \mathrm{g}$. protein $/ \mathrm{ml}$.) was achieved and was routinely used to obtain larger quantities of spheroplasts. One-litre flasks containing 250-300 ml. penicillin- or glycine-treated suspensions of organisms were incubated on a rotary shaker. After a period of 7-11 hr at $26^{\circ}$ over $95-98 \%$ of the organisms were converted to spheroplasts as determined by haemocytometer counts.

$S$ pheroplast fractionation. Spheroplasts were removed by centrifugation $(10,000 \mathrm{~g})$ from $1 \mathrm{l}$. of suspension at $4^{\circ}$ for $10 \mathrm{~min}$. All subsequent centrifugations were also performed at $4^{\circ}$. The spheroplasts were suspended in $30 \mathrm{ml}$. of $4 \times 10^{-3} \mathrm{M}$ - or $10^{-2} \mathrm{M}-$ potassium phosphate buffer ( $\mathrm{pH} \mathrm{7 \cdot 0}$ ) containing $2 \times 10^{-3} \mathrm{M}$-magnesium chloride and deoxyribonuclease (beef pancreas, $1 \times$ crystallized, Mann Research Laboratories) $10 \mu \mathrm{g} . / \mathrm{ml}$. Although considerable breakage was evident, complete spheroplast destruction was obtained by further homogenization with a motor-driven Teflon pestle. The resulting homogenate was spun at $32,000 \mathrm{~g}$ for $10 \mathrm{~min}$. The pellet obtained was resuspended in the phosphate + magnesium chloride buffer ( $\mathrm{pH} \mathbf{7 \cdot 0}$ ) without deoxyribonuclease and homogenized until no intact spheroplasts were detected by microscopy. The membrane pellet was washed twice in $20 \mathrm{ml}$. of the phosphate buffer + magnesium chloride solution and stored at $4^{\circ}$ until used. This membrane fraction contained an insignificant number of viable organisms as determined by agar plate counts. The combined supernatant fluids obtained after homogenization were termed the cytoplasmic fraction. Ribosomes were obtained by adjusting the supernatant fluid to $0.02 \mathrm{M}-\mathrm{MgCl}_{2}$ and spinning for $90 \mathrm{~min}$. at $\mathbf{3 8 , 0 0 0} \mathrm{rev} . / \mathrm{min}$. in a no. 40 rotor of a Model L Spinco ultracentrifuge. The ribosomal pellet was washed with $0.02 \mathrm{M}-\mathrm{MgCl}_{2}$ and recentrifuged.

Total ribonucleic acid was determined by extracting the various fractions with 
$0.5 \mathrm{~N}$-perchloric acid for $30 \mathrm{~min}$. at $70^{\circ}$ as modified after Basler \& Commoner (1956). The orcinol method of Ceriotti (1955) and absorption at $260 \mathrm{~m} \mu$ were two methods used to measure ribonucleic acid in the acid extract. Yeast ribonucleic acid (Worthington Biochemical Corporation) served as the standard.

Total protein and toxin determination. Protein was determined by a modified Lowry procedure (Oyama \& Eagle, 1956) with bovine albumin (crystallized, Pentex Incorporated, Kanakee, Ill., U.S.A.) as standard. Toxin was assayed by diluting the various fractions with distilled water and injecting $0.5 \mathrm{ml}$. intraperitoneally into 16-18 g. Swiss Albino mice; deaths which occurred within $24 \mathrm{hr}$ were recorded. Four mice were used for each dilution. The LD 50 dose was averaged from maximal and minimal lethal doses. Toxin concentration in a particular fraction was calculated by dividing the LD 50 dose, in $\mu \mathrm{g}$., into the total $\mu \mathrm{g}$. protein of each fraction and expressed as the total LD 50 (total toxic units).

Membrane disruption. To evaluate methods that might be used to isolate membrane-bound toxin and to gain insight into the structural relationship between the toxin and the membranes these were disrupted by various methods. In each case the treatments were concluded by centrifugation of the membrane suspension at $32,000 \mathrm{~g}$ for $10 \mathrm{~min}$. and assaying the resulting soluble and residue fractions for total toxin. To disrupt by sonic treatment, isolated membranes were suspended in $20 \mathrm{ml}$. distilled water or dilute phosphate buffer $(\mathrm{pH} 7 \cdot 0)$ and treated in a Raytheon $10 \mathrm{kc}$. Sonic Disintegrator for 2-6 min. at $5^{\circ}$. Trypsin $(2 \times$ crystallized; Worthington Biochemical Corporation) was used for digestion of isolated membranes; digestion was facilitated by slow agitation on a rotary shaker for from 2 to $5 \mathrm{hr}$. Membranes were also treated by suspending in sodium deoxycholate $(0 \cdot 1 \%, \mathrm{w} / \mathrm{v})$ or weak alkaline solutions (sodium hydroxide $\mathrm{pH} \mathrm{9-10)}$ ) and agitating the suspension for 2-5 $\mathrm{hr}$. Membranes were also disrupted by rapidly freezing aqueous membrane suspensions in thin layers, grinding with a pestle for a few minutes, then slowly thawing with further grinding.

\section{RESULTS}

\section{Toxin content of spheroplast and spheroplast fractions}

The spheroplast homogenate or the recombined isolated cytoplasm + membrane fractions displayed the highest specific toxic activity (lowest LD 50 value). The LD 50 of the recombined fractions decreased 60-70\% compared with the averaged LD 50 of these two components individually. Thus, cytoplasmic and membrane toxin complemented each other in expressing a more lethal effect. Cocking et al. (1960) found that the combined soluble extract and residue guinea-pig toxins of Pasteurella pestis exhibited a similar synergistic effect.

During a typical spheroplast conversion, total protein in these fragile forms increased three- to fourfold over that of the original culture. It was noted in many experiments that spheroplasts formed with glycine tended to contain more total toxin and protein in all fractions than those obtained by the use of penicillin. Most of the toxic activity appeared to reside within the cytoplasm, but at least $10 \%$ of the total toxin remained in the twice-washed membrane fraction (Table 1). This fraction contained 50-60\% protein on a dry-weight basis. In other experiments five subsequent washings continued to remove small amounts of protein, suggesting that the membrane was being disintegrated. The final washing contained 
minute amounts of RNA. It was found that $200 \mu \mathrm{g}$. RNA/mg. protein remained in the membrane fraction upon completion of the washing procedure.

A gelatinous opaque pellet consisting almost entirely of ribosomes was obtained when the cytoplasmic fraction was adjusted to $0.02 \mathrm{M}$ with $\mathrm{MgCl}_{2}$ and centrifuged at $38,000 \mathrm{rev} . / \mathrm{min}$. The washed pellet contained less than $1 \%$ toxin and protein of that of the intact spheroplast.

Table 1. Distribution of toxin and protein in Pasteurella pestis spheroplast fractions obtained with penicillin and glycine

The final volume of spheroplast suspension was $600 \mathrm{ml}$. for each treatment. Fractionation was carried out in $10^{-2} \mathrm{M}$-potassium phosphate buffer $(\mathrm{pH} \mathrm{7} \cdot 0)$.

$\begin{array}{llccc}\text { Treatment } & \text { Fraction } & \begin{array}{c}\text { LD 50 dose } \\ (\mu \mathrm{g} . \text { protein) }\end{array} & \begin{array}{c}\text { Total protein } \\ (\text { mg. })\end{array} & \begin{array}{c}\text { Total } \\ \text { LD 50 doses }\end{array} \\ \text { Penicillin } & \text { Cytoplasm } & 53 & \mathbf{5 7 \cdot 7 8} & 1,088 \\ & \text { Membrane } & 212 & \mathbf{2 3} \cdot 40 & 110 \\ \text { Glycine } & \text { Cytoplasm } & 50 & 63 \cdot 00 & 1,260 \\ & \text { Membrane } & 162 & \mathbf{2 4 . 6 0} & 152\end{array}$

Table 2. Comparison of the relative effectiveness of various methods in removing toxic protein from spheroplast membranes of Pasteurella pestis

The data from a series of experiments were used to estimate the relative effectiveness of a particular treatment. The methods listed below are in order of decreasing effectiveness $(++++=$ most effective).

\section{Method}

Sonic treatment

Sodium deoxycholate $(0 \cdot 1 \%) *$

Aqueous sodium hydroxide (pH 9-10)

Trypsin

Freeze, grinding and thawing

Control
Toxic protein solubilized

$+++$

$+++$

$++$

$+$

-

* Although a great deal of protein was released, the specific toxic activity (LD 50) present in the solubilized fraction was difficult to determine since deoxycholate enhanced toxin activity (also see Goodner et al. 1955).

Slight alkalinity favoured the solubility of toxin from lysed whole organisms. Spheroplasts were fractionated at $\mathrm{pH} 8.8$ as described in the Methods by substituting sodium borate buffer for the phosphate buffer in order to avoid possible selective precipitation of cytoplasmic toxin. Membranes so obtained contained over $70 \%$ of the total toxic activity of that found in membranes fractionated at $\mathrm{pH} \mathbf{7 \cdot 0}$. Relatively larger amounts of non-toxic protein were removed from membranes at $\mathrm{pH} 8 \cdot 8$ as compared to $\mathrm{pH} \mathbf{7 \cdot 0}$, suggesting that non-toxic particulate protein was also being solubilized. It was concluded that toxin could not be readily removed by washing from the membrane fraction, indicating that toxin was bound to the fraction which sedimented at $32,000 \mathrm{~g}$. 


\section{Release of toxin from the membranes by various agents}

Attempts were made to disrupt the membrane structure to test for the presence of a membrane-bound toxin by partial isolation and to elucidate the relationship of the toxin to the membrane. Sonic treatments of membrane suspensions for 2 min. significantly increased the specific toxic activity of the protein as compared with the untreated original suspension. A comparison of the methods used to remove and solubilize the toxin is shown in Table 2. Sonic treatment for 2-6 min. was the most effective method for the release of toxin. Quick-freezing, grinding and thawing, although releasing toxin from whole organisms, did not release appreciable amounts of toxin and total protein from isolated membranes.

Table 3. Comparison of the amounts of toxin and total protein released from 'glycine membranes' from Pasteurella pestis spheroplasts during sonic treatment, with and without $0.02 \mathrm{M}-\mathrm{MgCl}_{2}$

Membrane suspensions prepared as usual were subjected to three 2 min. sonic treatments. Control membranes were resuspended during each 2 min. treatment.

\begin{tabular}{|c|c|c|c|c|c|c|}
\hline \multirow[b]{2}{*}{ Fractions } & \multicolumn{3}{|c|}{ Membranes in water } & \multicolumn{3}{|c|}{ Membranes in $\mathbf{M g C l}_{2}$} \\
\hline & $\begin{array}{c}\text { LD } 50 \\
\text { dose } \\
(\mu \mathrm{g} . \\
\text { protein) }\end{array}$ & $\begin{array}{c}\text { Total } \\
\text { LD 50 } \\
\text { doses } \\
\text { (toxic } \\
\text { units) }\end{array}$ & $\begin{array}{l}\text { Protein } \\
\text { (\% of } \\
\text { total)* }\end{array}$ & $\begin{array}{c}\text { LD 50 } \\
\text { dose } \\
(\mu \mathrm{g} . \\
\text { protein) }\end{array}$ & $\begin{array}{c}\text { Total } \\
\text { LD 50 } \\
\text { doses } \\
\text { (toxic } \\
\text { units) }\end{array}$ & $\begin{array}{c}\text { Protein } \\
\text { (\% of } \\
\text { total)* }\end{array}$ \\
\hline \multicolumn{7}{|l|}{ Soluble } \\
\hline Sonically treated (1) & 79 & 80 & 45 & 83 & 20 & 15 \\
\hline Control & 83 & 22 & 12 & 83 & 19 & 9 \\
\hline Sonically treated (2) & 100 & 24 & 17 & - & 一 & 8 \\
\hline Control & - & - & 2 & - & - & 2 \\
\hline Sonically treated (3) & 一 & - & 8 & - & - & $\mathbf{1}$ \\
\hline Control & 一 & - & 1 & - & - & 2 \\
\hline \multicolumn{7}{|l|}{ Final residue } \\
\hline Sonically treated & $>205$ & - & $\mathbf{3 0}$ & $\mathbf{2 5 0}$ & $\mathbf{3 4}$ & 81 \\
\hline Control & $\mathbf{2 4 2}$ & $\mathbf{5 7}$ & 85 & 224 & 66 & 87 \\
\hline
\end{tabular}

* ' $\%$ of total' refers to the amount of protein present in each fraction relative to the total soluble protein + residue protein.

\section{Release of toxin by sonic treatment}

During sonic treatments it was found that an increase in $\mathrm{MgCl}_{2}$ concentration inhibited solubilization of toxin and membrane protein. Table 3 gives the results of a typical experiment with membranes from spheroplasts produced with glycine and submitted to sequential sonic treatments in order to remove the bulk of the toxin. Membrane material was suspended in distilled water or $0.02 \mathrm{M}-\mathrm{MgCl}_{2}$, sonically treated for $2 \mathrm{~min}$. and centrifuged. After resuspension this procedure was repeated twice for each sample before calculation of the data presented. Over $70 \%$ of the total protein was released from membranes suspended in water after three sonic treatments; this protein contained 104 LD 50 (total toxin units). By comparison, $20 \mathrm{LD} 50$ and $20 \%$ protein was released in the $\mathrm{MgCl}_{2}$ preparations. It should be emphasized that the LD 50 dose of released protein decreased about threefold below the initial membrane-bound protein. This observation and the 
previously mentioned results which showed an increase in the toxic activity of the sonically treated homogenates suggest that the potential toxic activity of bound toxin cannot be adequately expressed until the toxin is solubilized.

When $0.02 \mathrm{M}-\mathrm{MgSO}_{4}$ or $0.02 \mathrm{M}-\mathrm{NaCl}$ was substituted for $\mathrm{MgCl}_{2}$ in membrane sonic-treatment experiments, only $\mathrm{MgSO}_{4}$ afforded significant protection. It was concluded from these sonic treatments with membranes from glycine- or penicillinderived spheroplasts that magnesium ions protect the isolated membranes of Pasteurella pestis against disruption by sonic treatment. This effect of $\mathbf{M g}^{2+}$ is interesting in that Grossowicz (1962) reported that $\mathrm{Mg}^{2+}$ was needed to stabilize whole Pasteurella pestis organisms against lysis by lysozyme. In confirmation we have observed that whole organisms were protected against sonic treatment with higher concentrations of $\mathrm{Mg}^{2+}$. Sonic treatment of the cytoplasmic contents obtained from the spheroplasts and retreatment of toxic protein released from the membrane by sonic treatment did not alter the LD 50 dose of the initial preparations. It does not appear that sonic treatment affected soluble (i.e. unbound) toxin.

Table 4. The distribution of toxic protein and/or peptides between the soluble and residue fractions of glycine spheroplast membranes of Pasteurella pestis after treatment with trypsin

Trypsin (300 $\mu \mathrm{g}$.) was added to a $20.75 \mathrm{mg}$. membrane protein suspension and incubated at $37^{\circ}$ in $0.01 \mathrm{~m}$-potassium phosphate buffer (pH 7.0) for $135 \mathrm{~min}$. The control contained $20.25 \mathrm{mg}$. membrane protein similarly incubated but without enzyme. The 'total protein' and 'total LD 50' doses (total toxic units) are expressed as \% of total soluble protein + residue protein or toxicity.

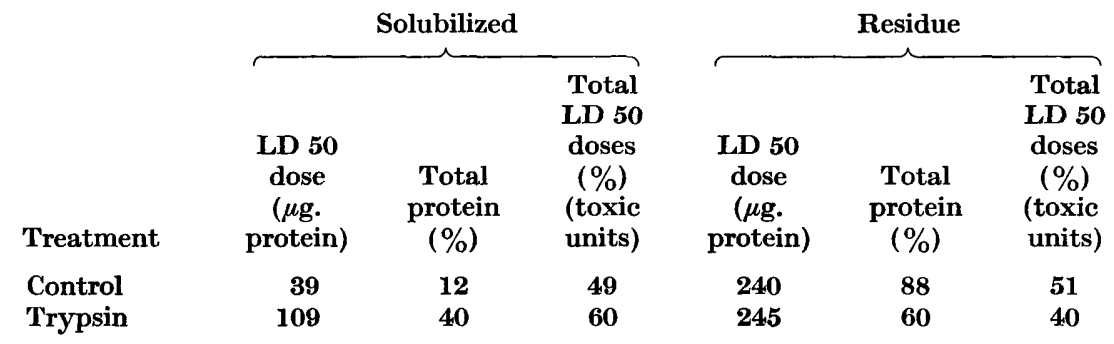

\section{The effect of trypsin on membrane disruption}

Ajl, Rust, Hunter, Woebke \& Bent (1958) reported that incubation of partially purified murine Pasteurella pestis toxin with trypsin did not significantly alter the toxicity of the preparation, although ninhydrin-positive material increased. Trypsin was therefore incubated with membrane suspensions in the hope of selectively releasing membrane toxin or of removing impurities while leaving toxin bound.

The LD 50 dose of solubilized membrane protein increased 2-4 times over that of the control (membrane + buffer; Table 4). This indicated that most of the protein released by trypsin was non-toxic. These results were in contrast to those from sonic treatment experiments, where the protein released was of high toxicity. In this particular experiment (Table 4) an unusually large degree of autolysis of the control membranes occurred which resulted in the release of highly toxic protein.

It would be expected that the loss of large amounts of non-toxic protein would 
be detectable as an increase in the remaining residue activity. Such an increase in residue activity was only detectable in experiments where the release of non-toxic protein was most pronounced. Incubation of toxin released by control membranes with trypsin showed no decrease in toxicity, substantiating the fact that trypsin does not destroy toxic activity. These results suggested that toxin may be bound in some manner which makes it inaccessible to trypsin action.

\section{Toxin synthesis at $26^{\circ}$ and $37^{\circ}$}

It has been reported that Pasteurella pestis alters its metabolic characteristics and requirements as a result of temperature changes (Surgalla, 1960). Burrows (1960) stated that preliminary results showed that spheroplasts incubated at $37^{\circ}$ contained $75 \%$ less non-diffusible antigen (apparently complexed material) than did organisms converted to spheroplasts at $28^{\circ}$. Experiments were made to test

Table 5. The distribution of toxin and protein in Pasteurella pestis spheroplasts produced by penicillin or glycine at $26^{\circ}$ or $37^{\circ}$

Spheroplasts were produced at $26^{\circ}$ and $37^{\circ}$ with penicillin or glycine, and cytoplasm and membranes isolated. The 'total protein (\%)' and 'total LD $50(\%)$ ' refer to \% of total cytoplasmic protein + membrane protein or toxicity.

\begin{tabular}{|c|c|c|c|c|c|c|}
\hline & & & Fra & ons & & \\
\hline & & ytoplasm & & & Aembrane & \\
\hline Treatment & $\begin{array}{c}\text { LD 50 } \\
\text { dose } \\
(\mu \mathrm{g} . \\
\text { protein) }\end{array}$ & $\begin{array}{c}\text { Total } \\
\text { protein } \\
(\%)\end{array}$ & $\begin{array}{c}\text { Total } \\
\text { LD 50 } \\
\text { (\%) } \\
\text { (toxic } \\
\text { units) }\end{array}$ & $\begin{array}{c}\text { LD 50 } \\
\text { dose } \\
(\mu \mathrm{g} . \\
\text { protein) }\end{array}$ & $\begin{array}{c}\text { Total } \\
\text { protein } \\
(\%)\end{array}$ & $\begin{array}{c}\text { Total } \\
\text { LD 50 } \\
\text { (\%) } \\
\text { (toxic } \\
\text { units) }\end{array}$ \\
\hline Penicillin & & & & & & \\
\hline 26 & 53 & 71 & 90 & 212 & $\mathbf{3 0}$ & 10 \\
\hline 37 & $>140$ & $40^{*}$ & $<\mathbf{5 7}$ & 272 & 60 & $>43$ \\
\hline Glycine & & & & & & \\
\hline 26 & $\mathbf{5 0}$ & 71 & 89 & 162 & 29 & 11 \\
\hline 37 & 119 & 61 & 78 & 276 & 39 & 22 \\
\hline
\end{tabular}

* Spheroplast lysis with penicillin is more pronounced at $37^{\circ}$ than at $26^{\circ}$. This observation might account in part for the low \% yield of cytoplasmic protein, which would be lost when harvesting the spheroplasts.

whether spheroplasts formed at $26^{\circ}$ or at $37^{\circ}$ differed in toxin content and distribution in the fractions studied earlier. After incubation at $37^{\circ}$ total synthesis of toxin and protein was inhibited as compared to $26^{\circ}$. Total protein decreased as much as $70 \%$ at the high temperature. Membrane fractions contained a greater percentage of toxin relative to cytoplasm when incubated at $37^{\circ}$ than at $26^{\circ}$ (Table 5). With penicillin, membrane toxin increased to over $43 \%$ of the total toxin in both fractions. This extreme shift in the relative location of toxin activity was seen in many experiments performed with penicillin; the effect was less pronounced when glycine was used in place of penicillin (Table 5). The specific activity of the penicillin membranes decreased $\mathbf{3 0}-\mathbf{4 0} \%$ at the higher temperature (Table 5), while the decrease in specific activity of the cytoplasmic fraction was more drastic, being 
almost a threefold loss at $37^{\circ}$. From this decrease in activity of both fractions it was concluded that at $37^{\circ}$ there was less protein synthesis and toxin production than at $26^{\circ}$. The increase in $\mathrm{LD} 50$ dose illustrates that less toxin existed relative to total protein at $37^{\circ}$ and suggests a selective inhibition of toxin production at this temperature. This selective effect was more pronounced in the cytoplasm than in the membrane fraction. Whether toxin was selectively degraded or its synthesis selectively inhibited remains to be determined. Synthesis inhibition seemed more likely when spheroplasts were examined microscopically ( $\mathrm{Pl}$. 1, figs. 1 and 2), because spheroplasts formed at $37^{\circ}$ (fig. 2) were smaller and contained a lesser amount of dense cytoplasmic material as compared with those at $26^{\circ}$ (fig. 1 ). By comparison, protein synthesis of whole organisms was inhibited over $50 \%$ and the specific toxin activity of the sonically treated organisms decreased $40 \%$ at $37^{\circ}$ as compared with $26^{\circ}$ when these suspensions were incubated under the same conditions but without penicillin or glycine. This suggests that, under the conditions used at $37^{\circ}$, inhibition was not an artifact of spheroplast induction but was a metabolic inhibition characteristic of the whole organisms.

\section{DISCUSSION}

The cytoplasmic toxin of Pasteurella pestis appears to exist as a non-conjugated non-particulate protein as deduced from the fact that a negligible amount of toxin was found in the ribosomes. In the case of the particulate toxin it may be asked whether the insoluble residue consists mainly of cell membrane. Bacterial cell membranes are composed primarily of protein and lipid (Hughes, 1962). It is, therefore, reasonable to assume that the membrane does contribute a large amount of the total protein of the residue and perhaps the bulk of the total toxin.

Clarke \& Lilly (1962) recently reported that Gram-negative bacteria contain a complex consisting of cell wall bounded on both sides by the membrane structure; one of these membranes appears to be attached to the cell wall. Hughes (1962) also suggested a closely associated wall-membrane complex in Gram-negative bacteria. Such a complex in Pasteurella pestis would make it difficult to evaluate the results presented here, in terms of two distinct separate envelope structures found in Gram-positive bacteria. It is interesting to note that, after vigorous stirring or homogenization, the $\boldsymbol{P}$. pestis membrane disintegrates into particles some of which float free. A similar fragmentation was reported by Mitchell \& Moyle (1957) with Staphylococcus aureus membranes. The gradual loss of protein and toxin from the $\boldsymbol{P}$. pestis membrane fraction during the washing procedures demonstrates the fragility of the cell wall + membrane complex in $P$. pestis. This apparent instability makes it difficult to arrive at definite conclusions concerning the precise amount of toxin and protein contained in the membrane and cytoplasm of the intact organisms.

The cytoplasmic membrane of Pasteurella pestis and the partially purified toxin released from autolysed whole bacteria apparently are identical. Both autolysed whole-organism toxin and cytoplasmic toxin from spheroplasts are purified by precipitation between 35 and $70 \%$ ammonium sulphate saturation (Ajl et al. 1955). The toxins (cytoplasmic, membrane, and autolysed whole organism) are increased in specific toxic activity by adding sodium deoxycholate, are not decreased in 
specific activity by trypsin digestion and show a similar protein band when chromatographed by acrylamide gel electrophoresis or by agar diffusion analysis (Ouchterlony, 1949). Final confirmation of the identity of the membrane and cytoplasmic toxins is being sought by further purification of each toxin so that their properties can be compared more precisely. The temperature studies suggest that the synthesis of membrane and cytoplasmic toxin, relative to total protein, decreases with an increase in temperature. Most interesting is the fact that the decrease is not proportional in both fractions. This decrease in total protein synthesis appears to be a reflexion of the increase in nutritional requirements of $\boldsymbol{P}$. pestis as a function of the temperature of incubation (Higuchi \& Carlin, 1958). In more recent experiments we had indications that, with phenylalanine-depleted spheroplasts, the amount of membrane toxin was decreased. Upon subsequent addition of phenylalanine for a short period of time, the membrane toxin increased $10 \%$ to $15 \%$ relative to total membrane protein, while an increase in cytoplasmic toxin was undetectable. These findings and the temperature studies indicate that the murine toxin of $P$. pestis may be synthesized selectively as the growth conditions are changed. If we assume that the membrane and cytoplasmic toxins are identical, a plausible hypothesis is that the toxin is synthesized within or on the membrane and is then transferred to the cytoplasm, where it accumulates as a soluble protein. That the membrane is a possible site of protein synthesis has been suggested by several authors (Butler, Crathorn \& Hunter, 1958; Hunter \& Godson, 1962; Mitsui, 1961; Spiegelman, 1959). Experiments are now in progress with labelled amino acids in vitro and in vivo with spheroplast fractions in an attempt to establish the exact location of toxin synthesis.

\section{REFERENCES}

AJl, S. J., Reedal, J. S., Durrum, E. L. \& Warren, J. (1955). Studies on plague. I. Purification and properties of the toxin of Pasteurella pestis. J. Bact. 70, 158.

AJl, S. J., Rust, J., Hunter, D., Woebke, J. \& Bent, D. F. (1958). Preparation of serologically homogeneous plague murine toxin and its reactions with physical, chemical and enzymatic agents. J. Immunol. 80, 435.

Basler, E. \& Commoner, B. (1956). The effect of tobacco mosaic virus biosynthesis on the nucleic acid content of tobacco leaf. Virology, $2,13$.

Burrows, T. W. (1960). Biochemical properties of virulent and avirulent strains of bacteria: Salmonella typhosa and Pasteurella pestis. Ann. N.Y. Acad. Sci. 88, 1125.

Butler, J. A. V., Crathorn, A. R. \& Hunter, G. D. (1958). The site of protein synthesis in Bacillus megaterium. Biochem. J. 69, 544.

Ceriotri, G. (1955). Determination of nucleic acids in animal tissues. J. biol. Chem. 214, 59.

Clarke, P. \& Lilly, M. D. (1962). A general structure for cell walls of Gram-negative bacteria. Nature, Lond. 195, 516.

Cocking, E. C., Keppie, J., Witr, K. \& Smith, H. (1960). The chemical basis of the virulence of Pasteurella pestis. II. The toxicity for guinea pigs and mice of products of Past. pestis. Br. J. exp. Path. 41, 460.

Englesberg, E. (1952). The irreversibility of methionine synthesis from cysteine in Pasteurella pestis. J. Bact. 63, 675.

Englesserg, E. \& Levy, J. B. (1954). Production of Pasteurella pestis toxin. J. Bact. 68, 57.

Goodner, K., Pannel, L., Bartell, P. \& Rothstein, E. L. (1955). Toxin and products from Pasteurella pestis. I. A comparison of lysate toxin with that obtained from the action of bile salts. J. infect. Dis. 96, 82. 
Grossowrcz, N. (1962). Protection against lysis of bacterial cells by spermine and its mode of action. Abstr. 8th Internat. Microbiol. Congr., Montreal, 1962, p. 32.

Higuchi, K. \& Carlin, C. E. (1958). Studies on the nutrition and physiology of Pasteurella pestis. II. A defined medium for the growth of Pasteurella pestis. J. Bact. 75, 409.

HuGres, D. E. (1962). Bacterial cytoplasmic membrane. J. gen. Microbiol. 29, 39.

Hunter, G. D. \& Godson, G. N. (1962). The final stages of protein synthesis and the role of lipids in the process. J. gen. Microbiol. 29, 65.

Mrtchelt, P. \& MoYıE, J. (1957). Autolytic release and osmotic properties of protoplasts of Staphylococcus aureus. J. gen. Microbiol. 16, 184.

MrTsur, H. (1961). Incorporation of amino acids into cytochrome $\mathrm{C}$ in a bacterial cell-free system. J. Biochem., Tokyo, 49, 411.

OUCHTERLONY, O. (1949). In vitro method for testing the toxin producing capacity of diphtheria bacteria. Acta path. microbiol. scand. 26, 516.

Oyama, V. I. \& Eagle, H. (1956). Measurement of cell growth in tissue culture with a phenol reagent (Folin-Ciocalteau), Proc. Soc. exp. Biol., N.Y. 91, 305.

Spiegelman, S. (1959). Protein and nucleic acid synthesis in subcellular fractions of bacterial cells, pp. 81-103. In Recent Progress in Microbiology, Symposium VIIth International Congress for Microbiology, Stockholm, 1958. Springfield, Ill.: Charles C. Thomas.

Surgalla, M. J. (1960). Properties of virulent and avirulent strains of Pasteurella pestis. Ann. N.Y. Acad. Sci. 88, 1136.

WARReN, J., WALz, U., Reedal, J. S. \& AJL, S. J. (1955). Studies on plague. II. Immunological properties of purified Pasteurella pestis toxin. J. Bact. 70, 170.

\section{EXPLANATION OF PLATE}

Spheroplasts of Pasteurella pestis formed in $1 \%$ glycine medium at $37^{\circ}$ and $26^{\circ}$. Phase microscopy, $\times 2000$.

Fig. 1. Larger spheroplasts at $26^{\circ}$.

Fig. 2. Spheroplasts decreased in size at $37^{\circ}$. 


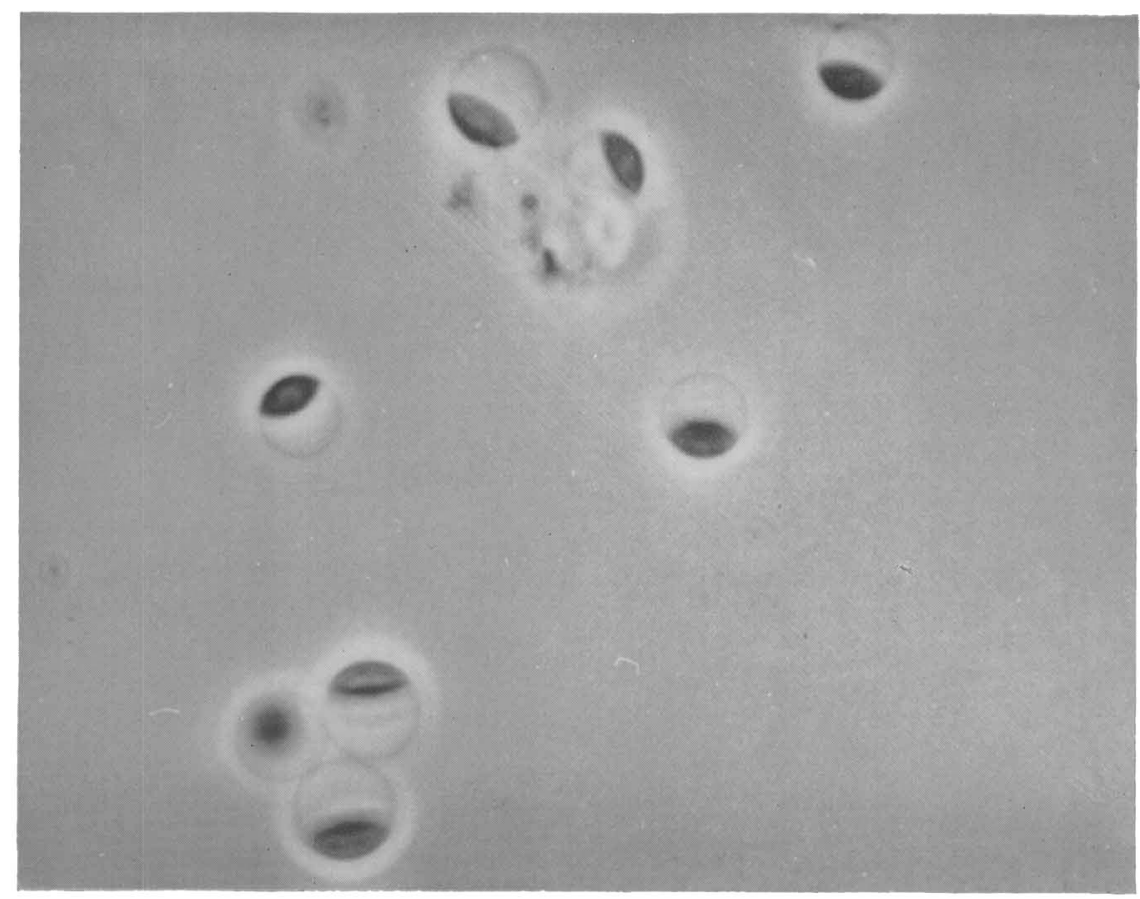

Fig 1

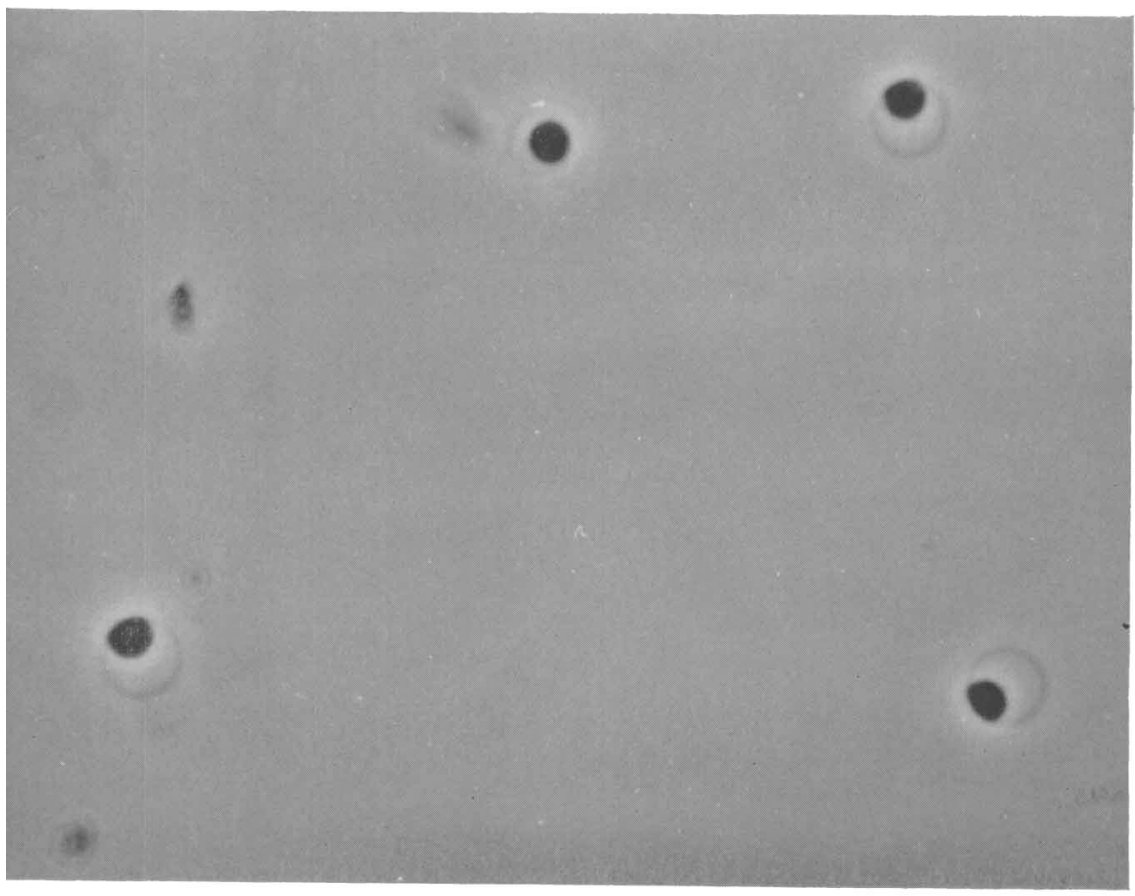

T. C. MONTIE ANU S. J. A.JL

Fig. 2 